\title{
Use Essential Oil And Power Of Antihelium Tsihanimposa To Eliminate The White Spot Syndrome Virus (WSSV) In Organic Shrimp Culture In Madagascar
}

\author{
A. Zafilaza, A. Andriantsimahavandy, and R. H. Randrianarivo
}

\begin{abstract}
The organic culture needs special treatment like treatment of the culture water to rid the different types of bacteria. Nosy Lonjo seawater contains bacteria like Coliforms $770 \mathrm{Npp} / 100 \mathrm{ml}$, Escherchia coli $700 \mathrm{Npp} / 100 \mathrm{ml}$, Intestinal Enterococci $2433 \mathrm{Npp} / 100 \mathrm{ml}$ and some viruses with Temperature $26{ }^{\circ} \mathrm{C}, \mathrm{pH} 9$, Conductivity $550 \mu \mathrm{S} / \mathrm{cm}$, Turbidity 0.9 NTU. Culture water (Seawater from Nosy Lonjo) also contains dissolved oxygen $6 \mathrm{mg} / \mathrm{l}$, Salinity $50 \mathrm{mg} / \mathrm{l}$, TCA ${ }^{\circ} \mathrm{f}$, NO31.8mg/l, Hardness $5780 \mathrm{mg} / \mathrm{l}$, Total iron 0mg /, Ammonium 0mg/l, Sodium 7006 mg/l, Potassium $350 \mathrm{mg} / \mathrm{l}$, Calcium 488 mb/l, Magnesium 1400mg/l, Aluminum 0mg/l, Copper 0.7 mg/l, Lead $0 \mathrm{mg} / \mathrm{l}$ and Chloride $348 \mathrm{mg} / \mathrm{l}$. After treatment with zanthoxylum Tsihanimposa oil and powder, the bacteria have almost disappeared as coliform bacteria with a rate of 10 Npp/100ml much lower compared to the EU 250 standard, Escherchia coli $0 \mathrm{Npp} / 100 \mathrm{ml}$ compared to EU 500, Intestinal enterococci $100 \mathrm{Npp} / 100 \mathrm{ml}$ compared to EU 200. Concerning viruses like Vibrio alginolyticus $1 \mathrm{Npp} / 100 \mathrm{ml}$, Vibrio anguilarum $0 \mathrm{Npp} / 100 \mathrm{ml}$, Vibrio harveyi $0 \mathrm{Npp} / 100 \mathrm{ml}$, Vibrio parahaemolyticus $1 \mathrm{Npp} / 100 \mathrm{ml}$, Vibrio vulnificus $0 \mathrm{Npp} / 100 \mathrm{ml}$ and Vbrio salmonica $0 \mathrm{Npp} / 100 \mathrm{ml}$, the presence in organic culture is almost null. The oil and powder of zanthoxylum Tsihanimposa also affects Pseudomonas aeruginosa 0 $\mathrm{Npp} / 100 \mathrm{ml}$, Flavoctrrium $2 \mathrm{Npp} / 100 \mathrm{ml}$ and Moraxella 1 $\mathrm{Npp} / 100 \mathrm{ml}$. The treatment of WSSV with zanthoxylum Tsihanimposa is a special case in our study, it lasts 90 days. The test is done every 10 days, after 20 days of culture the shrimp mortality is zero until 90 days of culture and the rate WSSV or White Spot Syndrome Virus is $0 \mathrm{Npp} / \mathbf{1 0 0 m l}$.
\end{abstract}

Index Terms - Zanthoxylum Tsihanimposa, White Spot Syndrome Virus (WSSV), treatment of culture, Organics Culture.

\section{INTRODUCTION}

The research would take place in the northern part of Madagascar and more precisely in the District of Ambanja, region DI.A.NA. In this region organics shrimp culture company called «LGA-OSO». This company is known on the world market by its brand OSO. Born in 2020, OSO is a source of national pride since it is the first project in the world to receive the $\mathrm{AB}$ label according to the standards of the French Ministry of Agriculture which have since been adopted by the European Union. OSO, a world pioneer in organic shrimp culture, is aslo a vertically integrated project. In late 2011, the White Spot Syndrome Virus present in the natural environment and transported by shrimps and crabs, arrived on the coast of Madagascar.

While the water supplying the culture, ponds is taken $80 \%$ from the natural environment and renewed every day, almost $20 \%$, the risks of contamination are always high. The virus was detected on May 5, 2012 at a Menabe farm near Morondava, owned by the Aquamen EF group, one of the two heavy weights in the sector on the Big Island alongside the UNIMA group. A potential disaster for the sector, because the virus is fatal for shrimp at more than $75 \%$. We had to isolate the farm and catch $100 \%$ shrimp to burn them explains an offial from the Menabe farm. We lost a complete cycle, around 300tonnes.

\section{A. Statement of Problem}

In 2011 all aquaculture companies in Madagascar were hit by the White Spot Syndrome Virus (WSSV). For 5 years all shrimp cultivation firms are closed, be it conventional or organic cultivation. This problem creates a budget deficit in the Malagasy State. All the shrimp culture forms are in technical unemployment. So, millions of dollars are missing in the country because it is the exported product that brings a lot of currency to Madagascar. Among the problem, it is the organic cultivation of shrimp in Madagascar that is why here are the objectives of my research.

\section{B. Objectives of the research}

The objectives are:

1. To solve the health problem and obesity that reigns in the world.

2. To develop the production of organic food such as organic shrimp.

3. To solve the various problems in the organic shrimp culture in Madagascar such as water treatment and production of organic shrimp food.

4. To get rid of the different bacteria and viruses that ravage organic farming in Madagascar like White Spot Syndrome Virus (WSSV).

5. Use oil and powder from the Zanthoxylum Tsihanimposa plant to kill bacteria and viruses. 


\section{STUDY AREA}

\section{A. Description of the region}

The Sambirano is rainy and is found in the DI.A.NA region. $90 \%$ of the population is made up of the Sakalava Bemazava ethnic group. In the Sambirano is the mangrove suitable for growing organic and conventional shrimp.

The Zanthoxylum Tsihanimposa grows in tropical forests, from 0 to $400 \mathrm{~m}$. altitude, on limestone or siliceous terrain on the western slope. It is found in the West (North Sector) on the limestone hills and plateaus of Ankarano in the Ambongo-Boina drive: middle basin of Bemarivo (Boina), Firingalava between Maevatanana and Andriba (Boina) and Morataitra near Maevatanana, Tampoketsa de l'Ambongo (Kelifely plateau). In the western Mahavavy basin. In the Menabe sector on the infra-Cretaceous sandstones of the lower Tsiribihina basin and in the Sambirano region on the Ankaramahifitry and Andampy mountains.

\section{B. Classification Zanthoxylum Tsihanimposa}

Genus comprising around 250 species in all hot regions, represented in the Malagasy region by two species from the Mascarenes and six species endemics to Madagascar. The two species of Mascareignes, unlike those of Madagascar which are i-carpellées, normally have flowers with 4 carpels.

Reign: Plantae

Sub-reign: Tracheobionta

Division: Magnoliophyta

Class: Magnoliopsida

Subclass: Rosidae

Order: Sapindales

Family: Rutaceae

Genus: Zanthoxylum

Species: Zanthoxylum Tsihanimposa

Vernacular name: Fahavalonkazo, Manongo, Manago [12, $13]$.

\section{Classification of the Virus}

Family: Nimaviridae.

Genus: Whispovirus.

Species: White spot syndrome virus.

Common name: White spot baculovirus (WSBV), white spot syndrome (WSS) [3].

Type: Virus White spot syndrome virus (WSSV) is the only virus (and type species) of the genus Whispovirus (white spot), which is the only genus in the family Nimaviridae. It is responsible for white spot syndrome in a large number of crustacean hosts [1]. White spot syndrome is a viral infection of penile shrimp. The disease is very deadly and contagious, quickly killing shrimp. Epidemics of this disease have destroyed the entire population of many shrimp farms in a matter of days, worldwide. The disease is caused by a family of related viruses included in the baculovirus white spot syndrome complex [2] and white spot syndrome (WSS) [3]. White spot syndrome virus is a dsDNA virus which places it in group I of the Baltimore classification system. WSSV is a form of rod, double stranded DNA virus, and the size of enveloped viral particles have been reported as 240-380 $\mathrm{nm}$ long and 70 to $159 \mathrm{~nm}$ in diameter and nucleocapsid nucleus is 120- $205 \mathrm{~nm}$ long and $95-165 \mathrm{~nm}$ in diameter. The virus has an outer lipid bilayer membrane envelope, sometimes with a tail-like appendage at one end of the virion. The nucleocapsid consists of 15 sharp vertical helices located along the long axis; each helix has two parallel streaks, composed of 14 globular capsomers, each of which has a diameter of $8 \mathrm{~nm}$ [8].

\begin{tabular}{|c|c|c|c|c|c|}
\hline Genus & Structure & Symmetry & Capside & $\begin{array}{c}\text { Genomic } \\
\text { arrangement }\end{array}$ & $\begin{array}{c}\text { Genomic } \\
\text { segmentation }\end{array}$ \\
\hline Whispovirus & $\begin{array}{l}\text { Ovoid } \\
\text { Form }\end{array}$ & & Wrapped & Circular & Monopartite \\
\hline
\end{tabular}

Genome: The complete DNA sequence of the WSSV genome has been assembled into a circular sequence of 292,967 bp [9]. Its codes 531 putative open reading frames. One of the proteins, WSSV449, has certain similarities with the host protein Tube and can function as a tube by activating the NF-KB pathway [10].

Life cycle Viral: The replication is nuclear; DNA-based transcription is his method. The virus infects an unusually wide range of crustaceans [1]. Transmission of the virus is mainly by oral ingestion and by water on farms (horizontal transmission) and vertical transmission (from infected mother shrimp) in the case of shrimp hatcheries. The virus is present in wild shrimp stocks, especially in coastal waters adjacent to shrimp farming regions in Asian countries, but massive mortality of wild shrimp has not yet been observed.

Hosts and replications: The virus have a wide range of hosts. While shrimp can survive with the virus for long periods of time, factors such as stress can cause the WSSV epidemic. The disease is very virulent and leads to mortality rates of $100 \%$ in a few days in the case of penaeid shrimps in culture. Most cultivated penaeid shrimp (Penaeus monodon, Marsupenaeus japonicus, Litopenaeus vannamei and Fenneropenaeus indicus) are natural hosts for the virus. Several non-reigning shrimps were also found to be seriously infected in experimental tests. Many crustaceans such as crabs (Scylla spp., Portunus spp.), langouste (Panulirus spp.), Crayfish (Astacus spp. Cherax spp.) And freshwater shrimps (Macrobrachium spp.) varying degrees of severity depending on the life of the host and the presence of external stressors (temperature, salinity, etc.). Bacterial diseases, pollutants).

Clinical signs of SAE include a sudden reduction in food consumption, lethargy, cuticle discoloration and often reddish, as well as the presence of white spots 0.5 to $2.0 \mathrm{~mm}$ in diameter on the inner surface of the carapace, appendages and cuticle on the abdominal segments.

TABLE II: SUMMARY OF VIRUS LIFE CYCLES

\begin{tabular}{|c|c|c|c|c|c|c|c|}
\hline Gender & Host details & Tissue tropism & Entry details & Exit details & Replication site & Mounting site & Transmission \\
\hline Whispovirus & Transmission & $\begin{array}{l}\text { Ectoderm, } \\
\text { mesoderm }\end{array}$ & Unknown & Unknown & Nuclear & Nuclear & Contact \\
\hline
\end{tabular}




\section{MethodS AND MATERIALS}

\section{A. Organic food manufacturing (Bio)}

In organic shrimp culture, the food used is a food produced in our research during a doctoral thesis. These are foods made from "Kabija and Spirulina". Pellet sizes are made according to the age of the shrimp. For a Pl 35 larva (i.e. 35 days of birth) up to 45 days of birth, the size of the granules is $2 \mathrm{~mm}$. After 45 days of birth until the end of the culture, that is to say until the desired size and weight of shrimp between $35 \mathrm{~g}$ to $60 \mathrm{~g}$ for 120 days to 140 days. The shrimp are fed 2 to 3 times a day and it is advisable to do it at night because the shrimp is a nocturnal animal and very dressed at night so that all the food is finished. These larvae originate from the LGAOSO aquaculture shrimp hatchery center. They come from organic parents, so without conversion and they are at the age of 40 days. After 40 days of birth, the larvae are harvested and placed in plastic bags filled with oxygenated salt water. In this case the transport journey takes 12 hours between LGA and the experimental culture center. They are off spring of Penaeus monodon (Tigre prawn) $[14,15,16]$.

\section{B. Bacteriological analyzes in culture water}

Preparation of culture water: Punctures need natural seawater for organic farming. In our studies, seawater is collected from Nosy lonjo in the Makiplast 2001 x 2 container. Before the use of seawater, it is analyzed to master the different types of parameters [14, 15].

\begin{tabular}{|c|c|c|c|}
\hline Parameters & Units & Tolerance & Optimum \\
\hline $\begin{array}{l}\text { Physical: } \\
\text { Temperature } \\
\text { salinity } \\
\text { pH } \\
\text { Dissolved } \\
\text { oxygen } \\
\text { Suspended } \\
\text { matter }\end{array}$ & $\begin{array}{c}{ }^{0} \mathrm{C} \\
\% 0 \\
{\left[\mathrm{H}_{3} \mathrm{O}\right]^{+}} \\
- \\
\% \\
\text { saturation } \\
\text { ppm FTU }\end{array}$ & $\begin{array}{c}20-36 \\
0-40 \\
6.5-9.5 \\
50-110 \\
<15\end{array}$ & $\begin{array}{c}30 \\
33 \\
8.2 \\
100 \text { Traces } \\
-\end{array}$ \\
\hline $\begin{array}{l}\text { Chemical: } \\
\text { Ammonium } \\
\text { Nitrite } \\
\text { Nitrate } \\
\text { Phosphate } \\
\text { Silicate }\end{array}$ & $\begin{array}{l}\mathrm{mg} / 1 \\
\mathrm{mg} / 1 \\
\mathrm{mg} / 1 \\
\mathrm{mg} / 1 \\
\mathrm{mg} / 1\end{array}$ & $\begin{array}{c}<0.1 \\
<5 \\
<10 \\
<5 \\
<100\end{array}$ & $\begin{array}{l}\text { Traces } \\
\text { Traces } \\
\text { Traces } \\
\text { Traces } \\
\text { Traces }\end{array}$ \\
\hline $\begin{array}{l}\text { Heavy metals: } \\
\text { Mercury } \\
\text { Plomb } \\
\text { Cadmium } \\
\text { Cuivre } \\
\text { Zinc }\end{array}$ & $\begin{array}{l}\mathrm{mg} / \mathrm{l} \\
\mathrm{mg} / \mathrm{l} \\
\mathrm{mg} / \mathrm{l} \\
\mathrm{mg} / \mathrm{l} \\
\mathrm{mg} / \mathrm{l}\end{array}$ & $\begin{array}{c}<0.1 \\
<5 \\
<10 \\
<5 \\
<100\end{array}$ & $\begin{array}{c}\text { Traces } \\
\text { Traces } \\
\text { Traces } \\
\text { Traces } \\
\text { Traces }\end{array}$ \\
\hline $\begin{array}{l}\text { Toxic agents: } \\
\text { Pesticides } \\
\text { Organochlorine } \\
\text { Heptachloride } \\
\text { Aldrin } \\
\text { DDT }\end{array}$ & $\begin{array}{l}\mathrm{mg} / 1 \\
\mathrm{mg} / 1 \\
\mathrm{mg} / 1 \\
\mathrm{mg} / 1 \\
\mathrm{mg} / 1\end{array}$ & $\begin{array}{l}<50 \\
<50 \\
<80 \\
<80 \\
<6\end{array}$ & $\begin{array}{l}0 \\
0 \\
0 \\
0 \\
0\end{array}$ \\
\hline $\begin{array}{l}\text { Hydrocarbons } \\
\text { (PCA) }\end{array}$ & $\mathrm{mg} / \mathrm{l}$ & $<10$ & 0 \\
\hline
\end{tabular}

C. Methods used to determine germs for microbiology

1. Method of H. Vincent: It is based on the identification of the isolated Colibacillus after seeding in carbolic peptone water and in incubation at $41{ }^{\circ} \mathrm{C}$. Hummingbird research is done on minimal amounts of water.
2. Modified techniques of Diénert: They are based on direct research of indole, in peptone water tubes with the water to be analyzed. Before the search for indole, one could inoculate the content of the tubes which gave a culture, on differential media after passage over carbolic media and incubated at 41 - 5C, as it was indicated to thereby obtain E.coli, Acetobacter [17]- [21].

3. For research on Enterococci: R. Buttiaux recommends a technique using a medium containing sodium azide (sodium azide) and an incubation temperature of $45^{\circ} 5 \mathrm{C}$. Sodium azide inhibits the culture of $\mathrm{Gram}^{-}$Bacilli and the high incubation temperature only allows the development of Enterococci. Depending on the importance of the seeding, the use of a simple medium or concentrated medium is necessary $[17,18,19,20,21]$.

4. For Salmonella research: The simplest method is to filter one or more liters of water on a Chamberland candle. When the filtration is complete, the candle is aseptically introduced into the flask containing 150 cubic $\mathrm{cm}$ of enrichment medium (Muller-Kaufman medium). And for alumina precipitation, the technique of Diénert Guillard is used [17] - [21].

\section{Sowing in the 400 l culture tank}

The tank filled with sea water is placed in a hangar. The larvae are sown in the tank with 10 larvae per $\mathrm{m} 2$. The water is changed every 7 to 10 days of culture to clean the culture medium. The addition of essential oil or "Tsihanimposa" powder is done once or twice a week during the water change with $5 \mathrm{ml}$ for essential oil per $\mathrm{m}^{2}$ and $5 \mathrm{~g}$ per $\mathrm{m}^{2}$ for the use of "Tsihanimposa" powder. The $\mathrm{pH}$, oxygen, turbidity and temperature measurements were made every morning every 2 days. Every day, the health of the shrimp is checked such as mobility, the rest of food ration. Food rations are referred to biomass. The role of water renewal is multiple: it leaches nutrient salts and phytoplankton from basins to limit blooms; it purifies toxic releases from metabolism, such as $\mathrm{NH}_{3}$. The culture water is diluted with water so that it does not reach excessive salinity; it can replace ventilation for loads less than $200 \mathrm{~g} \cdot \mathrm{m}^{-2}[14,15,16]$.

The daily water renewal is calculated according to the biomass of the livestock by Clifford's empirical formula:

Renewal (daily) $\left(\% d^{-1}\right)=\frac{\left(\text { Biomass }\left(\text { g.m }^{-2}\right)\right.}{10}+k$ (adjustement factor $)$

The ventilation for maintaining a dissolved oxygen level is optimal. Many old studies have shown that the main consumers of oxygen are the bottom of the pelvis and the water column and not the livestock itself. This is why the oxygen supply via mechanical ventilation must be evaluated according to the distributed quantities of granulate and the desired oxygen value and not according to the biomass of the livestock. The following empirical formula can be applied with profit [14] - [16].

$$
\begin{aligned}
& \text { Aeration (ch.ha } a^{-1} \text { or } \mathrm{m}^{-2} \text { ) } \\
& =\left[\frac{\left(\text { Granulated quatity }_{\text {average } 5 \text { days }}\right)\left(\mathrm{Kg}_{\mathrm{ha}} \mathrm{ha}^{-1} \cdot \mathrm{d}^{-1}\right)}{\left(28.23-4.31 \times\left[\mathrm{O}_{2}\right]\left(\mathrm{mg} \cdot \mathrm{l}^{-1}\right)\right.}\right] \times S
\end{aligned}
$$


The daily ration is calculated from the biomass:

$$
R T=B \times T N T
$$

where $R T$ : theoretical ration in $\mathrm{kg}$;

$B$ : biomass in $\mathrm{kg}$;

$T N T$ : theoretical nutrition rate in $\%$.

During the first month of breeding, the juveniles are fed with a fixed nutrition rate equivalent to 15 to $20 \%$ of the biomass. But from 50 days, the rate of nutrition increases by 3 grams of average weight compared to the amount of food distributed [14] - [16].

- Shrimp survival is calculated:

$$
S R V=\frac{N}{N} \times 100
$$

where $S R V$ : survival;

$N \mathrm{i}$ : initial number of shrimps;

$N$ : population size.

The shrimp biomass is calculated:

$$
B=N \times P m
$$

where $B$ : biomass;

Pm: average shrimp weight.

\section{E. Treatment of culture water with "Tsihanimposa" oil and powder}

Our study is divided into two:

- WSSV virus-free culture treatment;

- The culture treatment of shrimps infected with WSSV virus.

\section{1) WSSV virus-free shrimp culture treatment:}

$15 \mathrm{~g}$ of "Tsihanimposa" are required in the 4001 culture tank and $5 \mathrm{ml}$ of pure essential oil if you use essential oil. The treatment is repeated every 10 or 15 days depending on the length of the day of water change during the culture. In this analysis, the use of Api $20 \mathrm{NE}$ identifies bacteria, combined with 8 biochemical tests and 12 anabolic tests. In our crops and our research, the $\mathrm{P} 40$ post-larvae are used, i.e. larvae of 40-day shrimp weighing on average $5 \mathrm{~g}$. The shrimps are fed with organic foods that I made myself, formed from "Kabija and Spirulina" (see Doctoral Thesis).

2) Treatment of culture of shrimps infected with WSSV virus:

To eliminate the WSSV virus, the treatment is different from the first treatment. It takes $5 \mathrm{ml}$ of essential oil and 10 $\mathrm{g}$ of powder every 7 days and the water change is mandatory every 7 days. It is necessary to check the state of shrimp every 7 days to know the evolution of the white spots and their mobility of the shrimps which ensures their state. Many techniques are used but the most used is the examination under the microscope of light or dark parts; make a smear of lesion or organ blood then which will be placed on a coverslip follows observation under the microscope to observe the presence of a dark or light part in order to discover a typical incision or occlusion of the Baculovirus body (WSSV). And the antibody fluorescence technique, DNA and PCR analysis. In our research, the shrimps used are shrimps suffering from the disease called "white spots". 100 shrimps each weigh on average $10 \mathrm{~g}$ are sown in the 8001 tank. They are fed organic food made from "Kabija" and "Spirulina".

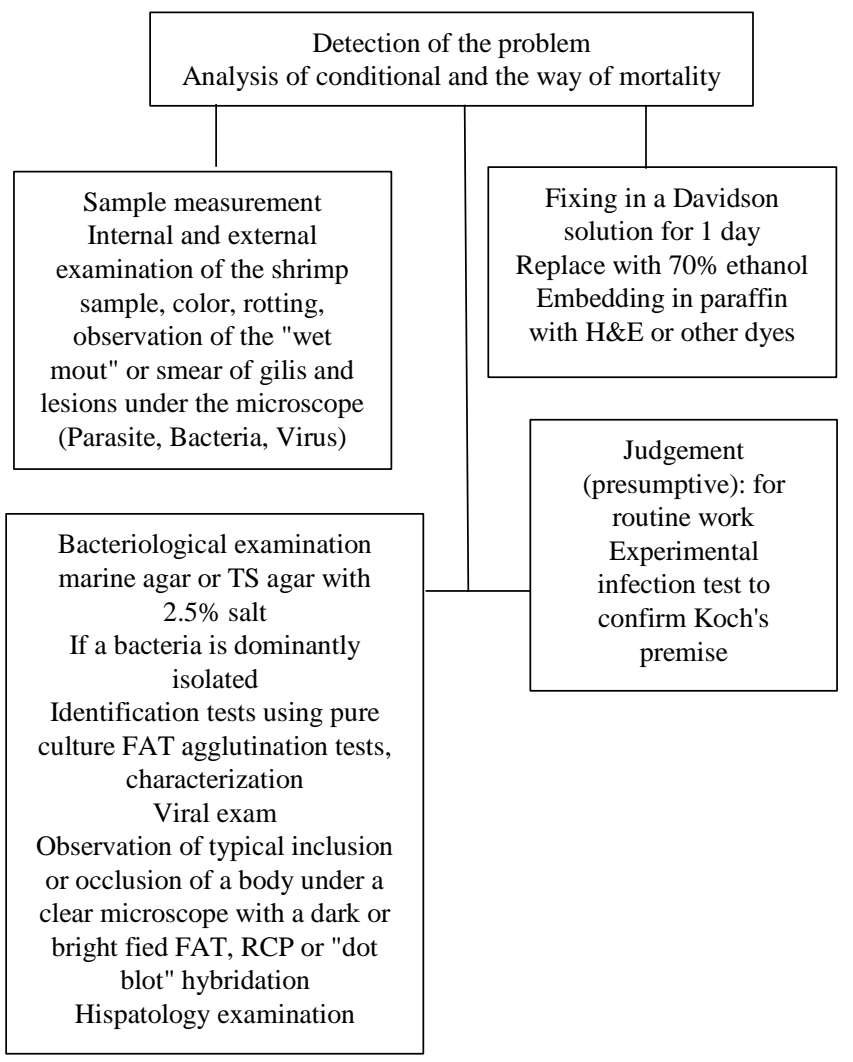

Fig. 1. Diagram of the diagnostic circuit.

\section{RESULTS AND INTERPRETATIONS}

A. Seawater analysis results

1) Physical parameters

TABLE IV: SUMMARY TABLE OF PHYSICAL PARAMETERS OF NOSY LONJO

\begin{tabular}{ccccc}
\multicolumn{5}{c}{ SEAWATER } \\
\hline \multirow{2}{*}{$\begin{array}{c}\text { Physical } \\
\text { parameters }\end{array}$} & Units & \multicolumn{3}{c}{$\begin{array}{c}\text { Standards in relation to drinking } \\
\text { water }\end{array}$} \\
\cline { 3 - 5 } & & WHO & EU & MS \\
\hline Temperature & $26^{\circ} \mathrm{C}$ & $<25$ & $<25$ & $<25$ \\
\hline$p H$ & 9 & 6.5 to 8.5 & 6.5 to 9.5 & $\begin{array}{c}6.5 \text { to } \\
9\end{array}$ \\
\hline Conductivity & $550 \mu \mathrm{S} / \mathrm{cm}$ & $180-1000$ & $180-1000$ & 3000 \\
\hline Turbidity & $0.9 \mathrm{NTU}$ & 5 & 5 & 5 \\
\hline
\end{tabular}

It is necessary to know the physical parameters of the culture water in order to master the biology of shrimp. The $\mathrm{pH}$ is equal to 9 with a temperature of $20{ }^{\circ} \mathrm{C}$. During cultivation, the shrimp needs temperatures varying from $21{ }^{\circ} \mathrm{C}$ to $34{ }^{\circ} \mathrm{C}$. 


\section{2) Chemical parameters}

TABLE V: Summary TABle Of Chemical Parameters Of Nosy LONJO SEAWATER

\begin{tabular}{lcccc}
\multicolumn{1}{c}{$\begin{array}{c}\text { Organic } \\
\text { parameters }\end{array}$} & Units & \multicolumn{3}{c}{$\begin{array}{c}\text { Standards relative to } \\
\text { drinking water }\end{array}$} \\
\cline { 3 - 5 } Dissolved oxygen & $6 \mathrm{mg} / 1$ & $<2$ & $<2$ & $<2$ \\
\hline Salinity & $50 \mathrm{mg} / 1$ & 0 & 0 & 0 \\
\hline $\begin{array}{l}\text { Alkalimetric titer } \\
\text { (TCA) }\end{array}$ & $12^{\circ} \mathrm{f}$ & $>11$ & $>11$ & $>11$ \\
\hline Nitrate $\left(\mathrm{NO}^{-3}\right)$ & $1.8 \mathrm{mg} / 1$ & 44 & 50 & 50 \\
\hline Hardness & $5780 \mathrm{mg} / 1$ & 50 & 50 & 50 \\
\hline Total iron & $0 \mathrm{mg} / 1$ & 0.2 & $<0.5$ & $<0.5$ \\
\hline Ammonium & $0 \mathrm{mg} / 1$ & $<0.5$ & $<0.5$ & $<0.5$ \\
\hline Sodium & $7006 \mathrm{mg} / 1$ & 200 & 200 & 200 \\
\hline Potassium & $350 \mathrm{mg} / 1$ & $<12$ & $<12$ & $<12$ \\
\hline Calcium & $488 \mathrm{mg} / 1$ & 400 & 400 & 400 \\
\hline Magnesium & $1400 \mathrm{mg} / 1$ & 50 & 50 & 50 \\
\hline Aluminum & $0 \mathrm{mg} / 1$ & $<0.2$ & 2 & $<0.2$ \\
\hline Copper & $0.7 \mathrm{mg} / 1$ & $<5$ & 5 & 5 \\
\hline Plomb & $0 \mathrm{mg} / 1$ & $<0.5$ & $<0.5$ & $<0.5$ \\
\hline Chloride & $348 \mathrm{mg} / 1$ & $<250$ & $<250$ & $<250$ \\
\hline
\end{tabular}

The importance of chemical analysis has been highlighted by this table. To be successful in cultivation, you have to master the chemical component of seawater. Stability of the elements is really a key to success.

3) Bacteriological analyzes

TABLE VI: MEASUREMENT OF BACTERIA FOR NOSY LONJO SEAWATER

\begin{tabular}{|c|c|c|c|c|}
\hline \multirow{2}{*}{$\begin{array}{l}\text { Types of } \\
\text { bacteria }\end{array}$} & \multirow[t]{2}{*}{ Units } & \multicolumn{3}{|c|}{$\begin{array}{l}\text { Standards relative to } \\
\text { drinking water }\end{array}$} \\
\hline & & WHO & EU & MS \\
\hline $\begin{array}{l}\text { Coliform } \\
\text { bacteria }\end{array}$ & $770 \mathrm{Npp} / 100 \mathrm{ml}$ & 150 & 250 & 250 \\
\hline Escherichia coli & $700 \mathrm{Npp} / 100 \mathrm{ml}$ & 250 & 250 & 500 \\
\hline $\begin{array}{l}\text { Intestinal } \\
\text { enterococci }\end{array}$ & $\begin{array}{c}2433 \\
\mathrm{Npp} / 100 \mathrm{ml}\end{array}$ & 100 & 200 & 185 \\
\hline Declaration & $\mathrm{NC}$ & & & \\
\hline
\end{tabular}

The table shows that there is the presence of bacteria with higher rates compared to the international standard in the sea of Nosy lonjo. Therefore, treatment is necessary during the cultivation of shrimp.

\section{B. Treatment of culture water with "Tsihanimposa" oil and powder}

\section{1) Shrimp culture treatment without WSSV virus (White Spot Syndrome Virus)}

After three months of culture, that is to say at the end of the shrimp culture, the water analysis shows the total absence of bacteria such as Vibrio alginolyticus, Vibrio anguilarrum, Vibrio harveyi, Vibrio parahaemolyticus, Vibrio vlnificus, Vibrio salmonicida. These are bacterial species pathogenic for shrimp. They produce pathogens like toxins, chitin enzymes in shrimp. The release of toxins causes necrosis of the epidermis of the cell, particularly that of the "nucleus" which communicates with other internal organs. In other bacteria like Flavobacterium, Moraxella, Coliform bacteria, Intestinal enterococci the reduction in rates are below authorized rates. And in other bacteria present there is the total disappearance like Escherichia coli. And the WSSV virus is completely absent.

TABLE VII: RESUlt SHOWING THE LEVEl OF BACTERIA AFTER THE POWDER AND OIL TREATMENT OF "TSIHANIMPOSA"

\begin{tabular}{lcc}
\hline \multicolumn{1}{c}{ Type of Bacteria } & $\begin{array}{c}\text { Rate after } \\
\text { treatment }\end{array}$ & $\begin{array}{c}\text { EU accepted } \\
\text { standard }\end{array}$ \\
\hline Coliform bacteria & $10 \mathrm{Npp} / 100 \mathrm{ml}$ & 250 \\
\hline Escherichia coli & $0 \mathrm{Npp} / 100 \mathrm{ml}$ & 500 \\
\hline Intestinal enterococci & $100 \mathrm{Npp} / 100 \mathrm{ml}$ & 200 \\
\hline Vibrio alginolyticus & $1 \mathrm{Npp} / 100 \mathrm{ml}$ & 150 \\
\hline Vibrio anguilarum & $0 \mathrm{Npp} / 100 \mathrm{ml}$ & 10 \\
\hline Vibrio harveyi & $0 \mathrm{Npp} / 100 \mathrm{ml}$ & 10 \\
\hline $\begin{array}{l}\text { Vibrio } \\
\text { parahaemolyticus }\end{array}$ & $0 \mathrm{Npp} / 100 \mathrm{ml}$ & 10 \\
\hline Vibrio vulnificus & $0 \mathrm{Npp} / 100 \mathrm{ml}$ & 5 \\
\hline Vibrio salmonicida & $0 \mathrm{Npp} / 100 \mathrm{ml}$ & 0 \\
\hline $\begin{array}{l}\text { Pseudomonas } \\
\text { aeruginosa }\end{array}$ & $0 \mathrm{Npp} / 100 \mathrm{ml}$ & 5 \\
\hline Flavobacterium & $2 \mathrm{Npp} / 100 \mathrm{ml}$ & 10 \\
\hline Acitnetobacter & $0 \mathrm{Npp} / 100 \mathrm{ml}$ & 5 \\
\hline Moraxella & $1 \mathrm{Npp} / 100 \mathrm{ml}$ & 5 \\
\hline
\end{tabular}
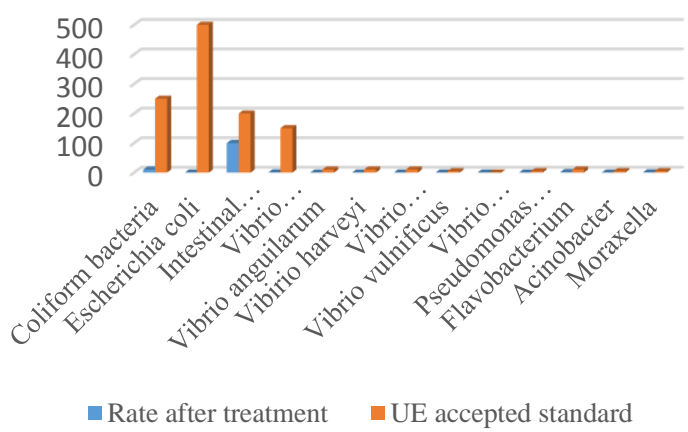

Fig. 2. Curve showing the levels of bacteria and vibrio after treatment with oil and Tsihanimposa powder.

2) Culture treatment of shrimps infected with WSSV virus (White Spot Syndrome Virus)

TABLE VIII: Result Showing The Mortality Rate After The POWDER AND OIL TREATMENT OF "TSIHANIMPOSA"

\begin{tabular}{ccc}
\hline $\mathrm{Xd}$ & $\mathrm{N}_{1}$ & $\mathrm{~N}_{2}$ \\
\hline $0 \mathrm{~d}$ & 100 & 0 \\
\hline $10 \mathrm{~d}$ & 96 & 4 \\
\hline $20 \mathrm{~d}$ & 92 & 4 \\
\hline $30 \mathrm{~d}$ & 90 & 2 \\
\hline $40 \mathrm{~d}$ & 88 & 2 \\
\hline $50 \mathrm{~d}$ & 88 & 0 \\
\hline $60 \mathrm{~d}$ & 88 & 0 \\
\hline $70 \mathrm{~d}$ & 88 & 0 \\
\hline $80 \mathrm{~d}$ & 88 & 0 \\
\hline $90 \mathrm{~d}$ & 88 & 0
\end{tabular}

$\mathrm{N}_{1}$ : Number of shrimps affected with WSSV seeded (Post larvae 40 days).

$\mathrm{N}_{2}$ : Number of dead shrimps every $\mathrm{X}$ day.

$\mathrm{X}_{\mathrm{d}}$ : Days of treatment with Tsihanimposa oil and powder. 


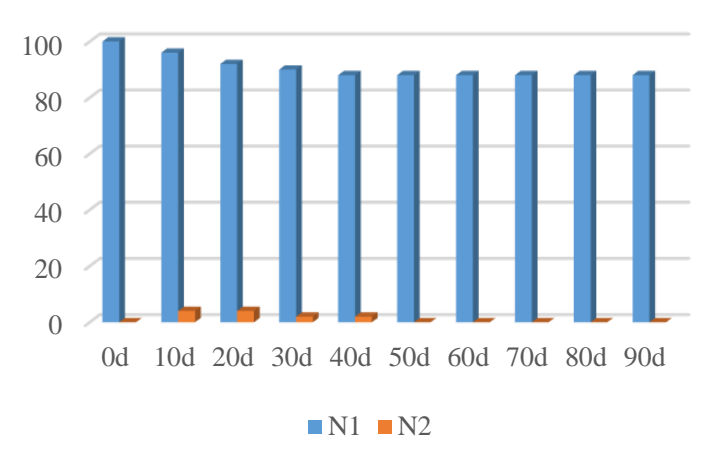

Fig. 3. Curve showing mortality rates of shrimp infected with WSSV virus after treatment with Tsihanimposa oil and powder.

Based on the result, the shrimp mortality rate drops depending on the number of days of treatment. After 10 and 20 days of treatment, 4 shrimp died. The mortality rate drops from 2 to 30 and 40 days of treatment. But, begins at 50 days of treatment, the mortality rate is zero up to 90 days of treatment, that is to say the end of culture. The result shows that 88 of post larvae reach maturity without WSSV litter after 90 days of culture, while 100 P140 infected with WSSV are sown.

\section{DISCUSSION}

One of the problems encountered in the cultivation of organic shrimp is the purification of water and the treatment of shrimp if they are suffering from diseases. Our research begins with the plant used for the treatment, it is the Zanthoxylum tsihanimposa plant also called "Fahavalonkazo, Manongo" which is used to solve the problems. It is composed of different molecules, the largest of which are (E) - $\beta$-caryophyllene with $29.56 \%$, 1,8-cineole $11.47 \%$, $\alpha$-humulene $7.28 \%$, Oxide $3.98 \%$ caryophyllene. There is also the presence of limonene with a rate of $1.97 \%$, of $\delta$-cadinene $1.98 \%$ and of $\beta$ and $\alpha$-selinene $1.37 \%$ and $1.89 \%$. There are other undetermined molecules with rates of $2.96 \%, 1.80 \%, 1.30 \%$. The different types of molecules in the plant ensure their effectiveness in countering different bacteria and viruses. In terms of phytochemicals, it is composed of primary, secondary, tertiary alkaloids and $\mathrm{N}$ oxides, flavonoids (flavones, flavonols, leucoanthocyans, anthocyanins), polyphenols and pyrogallic tannins, triterpenoids and unsaturated sterols. and polysaccharides. Phytochemicals play a crucial role in our research into water purification. They kill a lot of bacteria in our tests. Most terpenes are insoluble in water and terpenoid derivatives with the presence of oxygen groups have better solubility in water. Terpenes and terpenoids are also known for their biological and antioxidant properties. They have antimicrobial properties in the case of monoterpenes such as limonene and antivirals for the sesquiterpenes $\beta$-caryophyllene, 1,8cineole. In addition, in the case of terpenoids which have antibacterial properties exerted by oxygenated monoterpenes such as linanol against S. aureus and E. coli. And why do WSSV bacteria and viruses disappear?
First, phytochemicals: alkaloids are basic organic compounds that all contain at least one or more nitrogen atoms, found in primary, secondary or tertiary form. They are known for their many pharmacological properties. They have antibacterial activities (Gram- and Gram +) which seem to act by inhibiting the process of cell division in bacteria. Polyphenols also exhibit biological activities, taking particular interest in their antibacterial potential against Gram + and Gram- bacterial strains. The monophenol compound is capable of acting on different sites in the bacterial cell. Penetration inhibits bacterial growth like Escherichia coli, Pseudomonas aeruginosa, Actinetobacter, Moraxella and other types of molecules react with pathogenic viruses like Baculovirus and Vibrio alginolyticus, $V$. anguilarum, $V$. harveyi, $V$. parahaemolyticus, $V$. vulnificus. However, in other cases, shrimp carry the WSSV virus, the shrimp mortality rate equal to 0 after 50 days of cultivation of shrimp carrying WSSV. The treatment result shows that 88 shrimp mature after 90 days of culture which marks the end of culture. So, molecules come into play the most complex. The shrimp contains chitosine which has a natural antimicrobial capable of protecting the whole cell. But in the case of WSSV virus, chitosine does not act before the reliability of the virus. According to our research, the use of Tsihanimposa oil capable of ridding the WSSV virus. Chitosine is a biopolymer mainly from marine sources. These are renewable, biodegradable biological macromolecules which are formed by polymerization of simpler molecules or monomers linked together by so-called "covalent" bonds. Tsihanimposa oil contains $29.56 \%$ (E) - $\beta$ caryophyllene, $11.74 \%$ 1.8-cineole. These are sesquiterpenes capable of linking with chitosin molecules. Molecular complexes (1,8-cineole, $\beta$-caryophylene) - Chitosine come into play to ensure the different roles of the shrimp's immune system. And after viral activity, there are electrostatic interactions between the positive ammonium groups $(\mathrm{NH} 3+)$ of chitosine and the anionic groups in the surface of the viral cell. The molecule-chitosine complex penetrates inside the viral cell and interact with cellular compounds such as DNA or messenger RNA. Molecular complexes (1,8-cineole, $\beta$ caryophylene)-Chitosine inhibits the synthesis of messenger RNA. So, there is no mature virus because all messages are blocked which means that the transmission of genetic information will not take place. This is why, the use of Tsihanimposa oil and powder is very effective in organic cultivation to rid WSSV.

Given the effectiveness of this plant, the Sakalava Bemazava use it as a daily remedy against "Measles". It is the most effective plant against "Measles" in Madagascar, followed by other plants such as "Fagnazava and Lazalaza". The presence of different molecules makes the plant more effective as an antibiotic against different diseases.

\section{CONCLUSION}

Our research leads to a conclusion of the importance of conservation of the different biodiversity in Madagascar. The effectiveness of medicinal plants in the life of the population 
Sakalava Bemazava shows that the Zanthoxylum Tsihanimposa plant plays an important role in dealing with types of diseases such as diabetes, malaria and especially measles. It is very useful in the treatment of the measles that is currently used. The plant in composition with different phytochemicals such as alkaloids (primary, secondary, tertiary), flavonoids, tannins, polyphenols, triterpenes and polysaccharides. On the one hand, it contains molecules like $\beta$-caryophyllene $29.56 \%$, 1,8-cineole $11.47 \%$, $\alpha$-humilene $7.28 \%$, caryophyllene oxide $3.98 \%$ and limonene $1.97 \%$. It is also used in the treatment of shrimps infected with WSSV virus, one of the enemy viruses of organic and conventional shrimp culture. It is thanks to this plant that the virus disappears after 50 days of treatment. In shrimp culture, Zanthoxylum oil also inhibits the growth of bacteria such as Coliform bacteria, Escherchia coli, Flavobacterium, Actinetobacterium. The Zanthoxylum Tsihanimposa plant is endemic to Madagascar, given its heritage and medicinal value, it should precisely be protected, especially from disasters such as deforestation, land clearing, bush fires on the island which are especially likely to make the plants disappear. medicinal in our forests.

\section{REFERENCES}

[1] Accédez à:a b c "Zone virale". Dépaysement. Récupéré le 15 juin 2015.

[2] Résumés d'espèces non indigènes: "Complexe de Baculovirus de Syndrome de White spot (WSBV)". Commission des peches martimes des Etats du Golfe. 2003. Archive de l'orginal le 18 octobre 2005. Récupéré le 30 juin 2005.

[3] Lightner, DV. Un manuel de pathologie de la crevette et des procédures de diagnostic pour les maladies de la crevette pénéidé en culture. World Aquaculture Society, Baton Rouge, Louisiane, ÉtatsUnis, 1996.

[4] Huang, J.; XL Song; J. Yu \& CH Yang. "Nécrose baculovirale hypodermique et hématopoïétique : étude sur l'agent pathogène et la pathologie de l'épidémie épidémique de crevette". Recherche sur les pêches maritimes. 16: 1-10, 1995.

[5] Nadala, BCE Jr.; LM Tapay \& PC Loh. "Caractérisation d'un agent semblable à un baculovirus non occlus, pathogène pour les crevettes pénéides". Maladies des organismes aquatiques. 33 (3): 221-229, 1998.

[6] Van Hulten, MCW; J. Witteveldt; S. Peters; N. Kloosterboer; R. Tarchini; F. Fiers; H. Sandbrink; RK Lankhorst \& JM Vlak. "La séquence du génome de l'ADN du virus du syndrome des points blancs". Virologie. 286 (1): 7-22, 2001.

[7] Wang, PH ; Gu, ZH ; Wan, DH ; Zhang, MY ; Weng, SP ; Yu, XQ ; Lui, JG. "La voie NF-KB des crevettes est activée par le virus du syndrome des points blancs 449 pour faciliter l'expression du WSSV069 (c'est-à-dire), du WSSV303 et du WSSV371", 2011.

[8] Sautez vers:a b c Wongteerasupaya, C .; JE Vickers; S Sriurairatana; GL Nash; A. Akarajamorn; V. Boonseang; S. Panyin; A. Tassanakajon; B. Withyachumnarnkul \& TW Flegel. "Baculovirus systémique non occlus, présent dans les cellules d'origine ectodermique et mésodermique et entraînant une mortalité élevée chez la crevette tigrée noire, Penaeus monodon ". Maladies des organismes aquatiques. 21: 69-77, 1995.

[9] Wang, CS; KF Tang; GH Kou \& SN Chen. "Preuve au microscope optique et électronique de la maladie des points blancs chez la crevette tigrée géante Penaeus monodon (Fabricius) et la crevette kuruma Penaeus japonicus (Bate), élevée à Taïwan". Journal des maladies des poissons. 20 (5): 323-333, 1997.

[10] IT Chen, Aoki T, YU Huang, Hirono I, TC Chen, JY Huang, GD Chang, CF LK, Wang KC. Le virus du syndrome des taches blanches induit des modifications métaboliques ressemblant à l'effet de Warburg chez les hémocytes de crevette au stade précoce d'infection, 2011.
[11] Dhar, AK ; MM Roux \& KR Klimpel. "Détection et quantification du virus de la nécrose infectieuse hypodermique et hématopoḯtique et du virus des taches blanches chez la crevette à l'aide de la PCR quantitative en temps en temps réel et de la chimie verte SYBR". Journal of Clinical Microbiology. 39 (8) : 2835-2845, 2001.

[12] Perrier de la bathie, H. Rutacées (Rutaceae). Flore de Madagascar et des Comores (plantes vasculaires), familles 104-105. Firmin-Didot et cie., Paris, France. 89 pp, 1950.

[13] Rasoanaivo H.L. Contribution à l'étude chimique de Zanthoxylum madagascariensis Baker et Zanthoxylum thouvenotii H. Perr., Rutaceae: mise en evidence de l'activité molluscicide de décarine, alcaloïde caractéristique des Zanthoxylum de Madagascar. Thèse de Doctorat en Chimie, Spécialité produits naturels, Département de Chimie Physique, Faculté des Sciences, Université d'Antananarivo, Antananarivo, Madagascar. 109 pp, 2006.

[14] Rasoarinoro J., Sano M. Microbiologie de Base de l'aquaculture marine de crevette II. Rapport technique 4, vol 50, p: 7-8, 2000.

[15] Randrianasolonjanahary H., Suemitsu M. Le projet de développement de l'aquaculture de la Région côtière Nord-Ouest de Madagascar. Rapport technique 15, vol.149, 2000.

[16] Armand Z. Culture de Spirulina dans la région Nord-Ouest et utilisation comme aliment de base des larves de crevette Penaeus monodon. Mémoire de D.E.A. Biochimie Université d'Antananarivo, 2006.

[17] Afnor. Microbiologique alimentaire. Direction générale pour les examens pour le dénombrement de Staphylococcus aureus. Méthode pour le comptage des colonies NFV 08-014, 1506888, AFNOR, p: 113-120, 1984.

[18] Afnor. Microbiologique alimentaire. Methode de routine pour le dénombrement de Staphylocoques coagulases ( + ) par comptage des colonies à $57^{\circ} \mathrm{C}$. MFV08-057 AFNOR, p: 419-433, 1994.

[19] Afnor. Microbiologie des aliments. Méthode horizontale pour le dénombrement des Escherichia coli $\beta$-Glucuronidase (+) par comptage des colonies à $44^{\circ} \mathrm{C}$. NF ISO 16649-2, AFNOR, p: 1- 8, 2001.

[20] Disasi A. Étude phytochimiques et activité antibactérienne de quelques plantes médicinales de Kisangani (haut-zaïre), mémoire inédit, Fac. Sc., pp1416, 1988.

[21] Jabbar A., Khan Gams. Antimicrobial alkaloids from Euphorbia thymifolia. Pak J Sci Indian res, 8: 293, 1965.

[22] Avalle Olivier, Millous Olivier, Virmaux Jean-François ; 2003. Guide pour l'élevage de la crevette en zone tropicale. 92p,2003. 